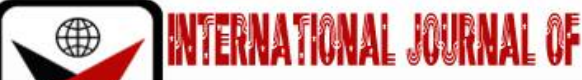

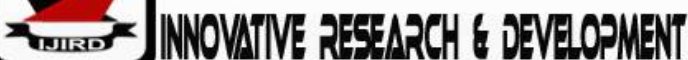

ISSN 2278 - 0211 (Online)

\section{Ideological Manipulation in the Translation of Tao Te Ching}

\author{
Wei Liu \\ Lecturer, School of Foreign Languages, Nanchang Normal University, China
}

\begin{abstract}
:
As a cross-cultural activity, translation concerns intertextuality not only in language terms but in cultural ones. Thus, in intertextuality perspective, the translation strategy employed by the translator is, in one way or another, influenced by the intertextual ideologies related to their respective languages, be it collision or acceptance. In this paper, the translation strategies of Tao Te Ching in different periods are discussed from intertextuality perspective and the ideological manipulation on the translators' choice of translation strategies are explored.
\end{abstract}

Keywords: Intertextuality, ideology, Tao Te Ching, translation of Chinese classic works

\section{Introduction}

As a classic representative of traditional Oriental philosophy and culture, Tao Te Ching covers all aspects of life, production, politics, military affairs, health maintenance, etc. It can be said that everything is incompatible and inclusive. It has attracted numerous domestic and foreign scholars to interpret and translate its profound meaning with its full range of words. Till now, there are over 100 foreign language translations, "more than 130 English translations alone", and [1] is the most widely translated Chinese classic. These translations have different characteristics due to the different times of their generation and the different ideological relations of intertextuality. From the perspective of intertextuality theory, this paper conducts a diachronic descriptive study on the dissemination and translation process of Tao Te Ching in the west, and summarizes its translation characteristics in different periods, aiming to reveal the influence of the intertextuality ideology relationship between the two cultures on the translation of Chinese classics.

I. Translation -- Ideological Manipulation in the Context of Intertextuality

As translation activities become more and more frequent, translation studies have stepped out of the trap of the traditional structuralist equivalence theory, and incorporated social, cultural and other external factors beyond the linguistic level into their research scope, moving toward interdisciplinary and cross-cultural development. People have realized the transformation on the level of translation is not just words, but also a cross-cultural communication activity, which will be influenced by such factors as culture, religion, ideology, the translator translation purpose, reader acceptance and so on etc. Therefore, more and more translators begin to probe into translation from cultural aspects, in which intertextuality and ideology are the key elements. They are not only closely related, but also play an important role in cultural and translation studies.

\subsection{Ideology and Translation}

The concept of ideology originated from the French philosopher Destutt DE Tracy in the early 19th century, who defined it as "the knowledge, thoughts, beliefs and values shared by all members of a certain group" [2]. Certain social ideology is the reflection of certain social existence. Althusser, a famous French philosopher and the founder of "structuralist Marxism", carried it forward and proposed that "ideology is an appearance with unique logic and structure -its contents include image, myth, concept or concept-system. In terms of specific forms, there are religion, ethics, philosophy, art, etc. "(ibid). Andre Lefevere, a scholar of the school of cultural translation, explored the connection between ideology and translation, saying that "ideology is constituted by the views and opinions accepted by a social group in a certain historical period, thus influencing the processing of texts by readers and translators. And the literature of a nation or country, culture to spread to another country, a nationality, the ideology of target language country or nation (ideology), and poetics (poetics) and sponsors (patronage) are three essential factors, the ideology of translation plays a big role in "[3]. When a translator wants to translate a text carrying a foreign culture and ideology into his own country, he will naturally serve a certain ideology, so it involves the exchange of double discourses. From this point of view, translation, as a typical cross-cultural activity, cannot be limited to the exchange of words at the language level. It is marked by the culture of the source text and the target text from the very beginning, and is an activity of ideological transmission and confrontation between the two cultures. 


\subsection{Ideology from the Perspective of Intertextuality}

Intertextuality is an important text theory advocated by western postmodernism scholars. It was formally proposed by Kristeva, a French semiologist, novelist and rhetorician. In 1989, when she absorbed the essence of Bakhtin's dialogue thought and polyphony theory and criticized the limitations of structuralism. She believes that any text is produced on the basis of the vestige or memory of its previous texts, or is formed through the absorption and transformation of other texts.Compared with the previous translation theory, the biggest difference of intertextuality theory is that it sees translationagainst an open, diverse, dynamic network of intertextuality, emphasizes imitation absorption, transformation and influence among literary texts, thus "broke the dominance of the original-targeted principle, shifted translation from language transfer to a three-dimensional interaction of words and other domains, greatly expanding the scope of translation studies and horizon" [4].In the intertextuality theory, translation is a process of intertextuality, not only on the language level in a narrow sense, but also on social and cultural aspects other than language, which includes the fusion of two cultural ideologies, as well as the transmission and competition of intertextuality between them. The creation and translation of the original background is inseparable from the respective ideology, the translator, in the intertextuality reading and interpretation of the original memory, inevitably subject to the influence of the morphological characteristics of both cultures. So, the analysis of the translation of classics in different periods can help us better understand the intertextuality interpretation of Chinese classic works in the English world.

\section{Ideological Manipulation in Tao Te Ching Translation in Its West-World Spread}

Tao Te Ching, originally named Laozi, was written by laozi during the Spring and Autumn Period and the Warring States Period. Tao Te Ching consists of 81 chapters, focusing on the philosophical concept of "Taoism", expounding the origin, mode of existence, law of movement and development of all things in the world and the solutions to social conflicts. It is the first philosophical work with a complete system in the history of Chinese philosophy. In the early 1860s, Tao Te Ching drew great attention in the west, and was translated abroad in many foreign languages. During this period spanning over one hundred years, there were 3 large-scale translation surges of Tao Te Ching, this paper attempts to give a diachronic description of the 3 climaxes and their characteristics respectively and discusses the ideology of intertextuality in each period of its translation strategies and characteristics.

\subsection{Early Dissemination of Tao Te Ching (1868-1915)}

During this period, western imperialist powers pried open China's door with foreign guns and cannons and invaded China's territory. In order to strengthen its ruling, British imperialism use religion as a tool, and Tao Te Ching was selected intranslation. The translator then was mostly missionary or clergy, who produced a total of 14 English translation, and eight of them have obvious Christian analogies, using a large number of Christian concepts in translation, such as the popular Alexander (George Gardiner Alexander) version at the end of the 19th century. The other six tried to respect the thoughts and contents of the original text, but also reflected Christian thought more or less. For example, Legge (James) translation is regarded as the most rigorous and is of great academic value in this period. He translated "吾不知谁之子, 象帝之先" in the fourth chapter into"I do not know whose son it is: it might appear to have been before God." the translation used two speculative words "might have been" and "appear" to weaken the affirmative tone of the original text, denying the possibility of "Taoism" before "emperor" and strengthening the intertextuality of Christianity. There are two reasons for this. On the one hand, during this period, the translating activities of Tao Te Ching into English were only tools for western clerics to spread Christianity. Most translators chose to rewrite favorable chapters for the spread of Christianity to cater to the western mainstream ideology, so as to consolidate the rule of the country and spread religious thoughts. On the other hand, even a Sinologist like James Legge, who, while respecting the original text and the culture of the target language, strives to faithfully reflect the content and essence of the original text in the process of translation, will bring in Christian ideas in the process of translation due to his Christian preconceptions and his intertextual reading experience. For example, in Alexander's translation, "God" is invariably used to replace "Tao", the key word with the most central meaning in Taoism, and "He", a personal pronoun, is used to translate the non-personal person in Taoist thought. The Christian analogies tendency is evident in The English translation of the title: Lao Tsze, The Great Thinker with a Translation of His Thought on The Nature and The Manifestation of God. Another example is Alexander's interpretation of Tao Te Ching's first chapter, "Tao can be Tao, Tao cannot be Tao; Names are names, very names." Translated into "God (the great everlasting infinite First Cause the from disappearance of all things in heaven and earth proceed) can neither be defined nor named."[5] the core word "Tao" is translated into "God" (God), which is compared to the First Cause in western philosophy and religion, and is referred to by the personal pronoun "he". The beginning of heaven and earth is translated as "Creator", which thoroughly transformed the "Tao" in the Tao Te Ching, which represents the general law of everything in the universe, into the religious god of the western world, making people feel like reading the New Testament. It can be said that Alexander's translation rewrote a lot of the original content, which reflected the arbitrary distortion of the ideology of the strong culture to the weak culture at that time, and reflected the dismissive and overlooking attitude of the west to Chinese culture at that time. It is not difficult to see from this that the early western translation of Tao Te Ching was influenced by the dominant ideology of western colonizers -- Christian culture -- from the perspective of translator's identity, translation purpose, translation skills and strategies, and cultural communication. Its purpose is to reshape the image of foreign literature by manipulating the ideological content of alien literary works and to form the thinking model and values of ethnocentrism. 


\subsection{Middle Translation of Tao Te Ching (1915-1972)}

In the 20th century, a series of social problems appeared in western society, such as energy crisis, ecological deterioration, economic crisis, etc. While questioning western civilization, people also sought solutions from Oriental wisdom in its classics. Therefore, in this period of the Tao Te Ching translation surge, the translator's translation purpose has changed, and the ideology of intertextuality relationship also has quietly changed. The translator no longer intentionally looked it as a reflection of Christianity in eastern world, but with a relatively objective and rigorous attitude to convey the Tao Te Ching containing the wisdom of philosophy to the western readers and reflecting the strong academic consciousness. It is not difficult to find that western translators of this period changed in their attitude toward Chinese culture. There were 25 English translations during this period, among which the most widely spread and far-reaching version was that of the British scholar Arthur Waley. His translation of Tao Te Ching basically retains the aphoristic style as well as the concise language and profound meaning of the original work, accurately conveying the philosophical thoughts of the original text. However, there was still an unequal attitude towards Chinese culture in the west during this period. It can be seen from the translation of the word "sage" in the third chapter. Most translators of this period translated it into religious terms, such as "the Master", "the Saint", and "the man of calling" by Waley, reminiscent of his Master in the gospels of the bible. Only a few scholars with an objective view of Chinese culture translated it into "sage", such as Waley. During this period, although many scholars regarded Tao Te Ching as the future development philosophy of the world out of the need to solve the malpractices and social contradictions of the western society, their interpretation still could not avoid the constraint of western ideology, which was more or less reflected by western religion.

\subsection{Late Dissemination of Tao Te Ching (1973-2004)}

Compared with the previous high tide of translation, this period showed a trend of diversification in terms of the selection of original versions, the number of translated versions, the cultural background of translators and the perspective of translation. There were more than 80 English translations in this period, and the nationalities, cultural backgrounds, educational backgrounds and ideologies of the translators varied. In this period, the intertextuality between the two ideologies of translators was more about fusion and transmission rather than confrontation and conflict. Therefore, even the intertextuality of the original text was adapted to meet the needs of the general public rather than the contempt of the source language culture. Take the most widely accepted "civilian version" by Stephen Michelle in this period for example. Her translation has carried on the bold reform to give more inter-textual explanation to the obscure original text by the use of familiar common terms in order to convey the Tao Te Ching wisdom of philosophy connotation to the foreign readers. For example, in chapter 46, the original texts goes : "when the world is in line with the Tao, the horse transport manure in the field, when it goes against Tao, horses line up for war." in her translation, she replaced horse with trucks, military horse with warhead, which goes "When a country is in harmony with the Tao, factories make trucks and tractors, and when a country goes counter to the Tao, the warheads are stockpiled outside the cities. "[6]By replacing such words as "horse" that are not familiar with modern people with "factory" and "tractor", she makes suggestion of intertextuality close to the western readers, guiding the general public to understand and accept Taoist culture.

In addition, this period also has another outstanding characteristic, a large number of Chinese scholars and Chinese American scholars immersed in the study of Chinese culture have devoted themselves to the cause of translating Tao Te Ching into English. They are familiar with the languages and cultures of China and Britain, and take it as their duty to spread the traditional Chinese classics. They strived to convey the purpose and essence of the original text objectively and rigorously in the process of translation, and fully reproduce the beauty of language and style of the original text. Representative translators such as Liu Dianjue, Lin Zhenshu, Chen Rongjie, Chen Wanxin, etc., whose translations are widely respected in the English-speaking world, thus have a large circulation, a large number of readers, and the translation strategy has been mainly alienated translation.

So to speak, during this period, began to face up to the western world, accept and welcome Chinese culture and philosophy, in the context of this kind of intertextuality, the translator is no longer blindly to the original "gouge out nose and eye", "cut", instead of standing in a more rigorous, objective stance to understand, interpret and translate the Tao Te Ching, in the intertextuality of sexual relations, the thought of the wisdom of the Tao Te Ching and meaningful along with its rich cultural connotation to the language of full show in front of the western readers.

\section{Conclusion}

It is easy to note that during the translation and dissemination of Tao Te Ching in the English-speaking world in various periods, translators have been restricted by the two cultural ideologies. With the increasing integration of cultural exchanges, the translation of Tao Te Ching is gradually getting rid of the intertextuality of western religions and gradually returning to its true nature. Therefore, the intertextuality ideology relationship of translators has been changed. Translation does not happen in a vacuum. Translators always intertextualize the original text in a specific culture. When introducing an idea contained in the discourse of an exotic culture into the local culture, "one must make one's own value judgment on the values of the exotic culture, and then decide the strategy to convey: to be direct or in a more roundabout way."[7] However, no matter which strategy, translators cannot get rid of their grasp of the text and the sociocultural intertextuality beyond the text. With the breaking down of cultural barriers in the world, Chinese philosophy and culture have become the focus of more and more countries. Interpreting the ideology in English translation works from the perspective of intertextuality can bring new inspiration to its dissemination and research, help us better understand translation activities, and improve our ability to deal with the intertextuality between text and social culture in translation activities. 


\section{Acknowledgment}

This paper is funded by 11531 projects of Nanchang Normal University

\section{References}

i. Xin Hongjuan. Tao Te Ching in the English world: text travel and world imagination [M], Shanghai translation publishing house, 2006.

ii. Qin Wenhua. Intertextuality in translation studies [M], Shanghai translation publishing house, 2008.

iii. Ji Guangmao. Ideology [M]. Guilin: guangxi normal university press, 2005.

iv. Susan and Andre Lefevere. Constructing Cultures: Essays on literary translation [M]. Shanghai: Shanghai Foreign Language Education Press, 2001.

v. Alexander, George Gardiner. The Great Thinker with a Translation of His Thoughts on The Nature and Manifestations of God [M]. London: Kegan Paul, Trench, Trubner \& Co, Ltd., 1895:55-56.

vi. Michael, Stephen. Tao Te Ching. New York: Harper Collins Publishers. 1988.p.x.

vii. Wang Dongfeng, An Invisible Hand -- on the manipulation of ideology in translation practice [J], Chinese translation, 2003(9). 